\title{
Well-being: Studi Sosiodemografi di Ambon
}

Desi $^{1}$, Shiren Junet Tomasoa ${ }^{1}$, Simon Peter Soegijono ${ }^{2}$

Program Studi Ilmu Keperawatan Fakultas Kedokteran dan Ilmu Kesehatan Universitas Kristen Satya Wacana ${ }^{1}$

\section{Universitas Kristen Indonesia Maluku ${ }^{1}$}

Kutipan: Desi, Shiren Junet Tomasoa, Simon Peter Soegijono. (tahun). Well-being: Studi Sosiodemografi di Ambon. Jurnal Keperawatan Muhammadiyah, 2 (2)

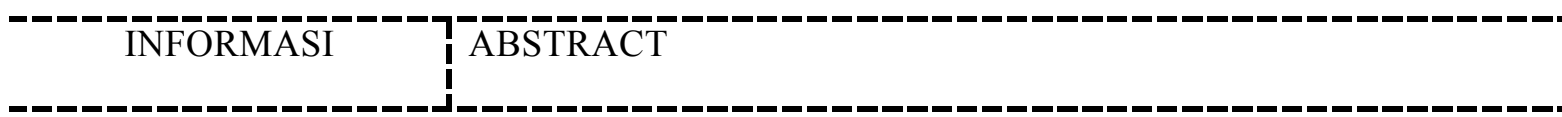

Well-being is deifined as a positive condition that enables an individual,

Korespondensi

desi@staff.uksw.edu

Keywords:

Sociodemographic profile, well-being, a group, or a country to become prosperous. This condition is highly essential to be achieved and improved, since everyone has a purpose to get a better life towards the prosperity. This research was aimed to investigate the relationship between sociodemographic (age, sex, marital status, occupation and income) and the well-being level measured by 3 things, they were positive and negative affection, positive and negative thoughts and psychological well-being in Ambon society, especially in RT 004/03 Kelurahan Batu Gajah, Sirimau District. This study was using quantitative method with Pearson Product Moment correlation test analysis and the data collection was using well-being questionnaires of Scale of Positive and Negative Experince (SPANE), Positive Thinking Scale (PTS), and Scale of Psychological Well-Being $(P W B)$, which were further adapted to Indonesian Language. The obtained result showed that most respondents were those in the productive age of 17-25 years old (36\%), males (52,7\%), Senior High School graduates $(74,1 \%)$, jobless people $(37,5 \%)$, with the income Rp. 500.001-1.500.000 (30\%) and marital status (48,2\%). A total of 46,4\% respondents perceived that they often experienced positive affection, 69\% respondents had the most positive thoughts and had the high psychological well-being were about $66 \%$ respondents. There was no relationship between positive and negative affects as well as positive and negative thoughts on sociodemography except on the work of positive and negative thinking. There was a significant association in the sociodemographic variables of age and occupation toward psychological well-being. 


\begin{abstract}
Abstrak
Well-being diartikan sebagai suatu keadaan positif yang memungkinkan seseorang, kelompok, ataupun suatu negara menjadi sejahtera. Kondisi ini sangatlah penting untuk dicapai dan terus ditingkatkan karena setiap orang memiliki tujuan untuk mendapatkan hidup yang lebih baik dan mengarah pada kesejahteraan. Penelitian ini bertujuan untuk mengetahui hubungan antara profil sosiodemografi (usia, jenis kelamin, status pernikahan, pendidikan, pekerjaan dan pendapatan) dengan tingkat well-being yang diukur dari 3 hal yaitu afek positif dan negatif, pemikiran positif dan negatif serta kesejahteraan psikologis masyarakat Kota Ambon khususnya di RT 004/03 Kelurahan Batu Gajah Kecamatan Sirimau. Penelitian ini menggunakan metode kuantitatif dengan analisis uji korelasi Pearson Product Moment sedangkan pengumpulan data menggunakan kuesioner well-being yaitu Scale of Positive and Negative Experince (SPANE), Positive Thinking Scale (PTS), dan Scale of Psychological Well-Being (PWB) yang selanjutnya diadaptasi ke bahasa Indonesia. Hasil penelitian yang ditemukan dalam profil sosiodemogarafi menunjukkan bahwa responden yang paling banyak adalah responden pada usia produktif 17-25 tahun $(36 \%)$, berjenis kelamin laki-laki $(52,7 \%)$, pendidikan SMA $(74,1 \%)$, tidak bekerja (37,5\%), berpendapatan Rp. 500.001- 1.500.000 (30\%) dan status pernikahan menikah (48,2\%). Sebanyak 46,4\% responden menilai bahwa mereka sering mengalami afek positif, $69 \%$ responden memiliki pemikiran paling positif dan memiliki kesejahteraan psikologis yang tinggi sebanyak 66\% responden. Tidak ada hubungan antara afek positif dan negatif serta pemikiran positif dan negatif terhadap sosiodemografi kecuali pada pekerjaan terhadap pemikiran positif dan negatif. Ada hubungan yang signifikan pada variabel sosiodemografi usia dan pekerjaan terhadap kesejahteraan psikologis.
\end{abstract}

Kata Kunci: Well-being, profil sosiodemografi 


\section{Pendahuluan}

Seorang ahli filsuf terkenal Aristoteles, pernah menyatakan bahwa kebahagiaan adalah tujuan utama dari eksistensi manusia dan kebahagiaan ini dapat dirasakan seseorang jika seorang tersebut merasa sejahtera (dalam Djabumir, 2016). Dalam hal ini terdapat 2 pandangan filsafat tentang kebahagiaan yaitu pandangan hedonic dan eudaimonic. Keduanya berasal dari bahasa Yunani yang berarti kesenangan dan kebahagiaan. Pandangan hedonic merupakan suatu pandangan yang lebih memunculkan afek positif dan menghilangkan afek negatif. Pandangan ini lebih subjektif sehingga fokusnya pada bagaimana cara seseorang mencari emosi positif dalam kehidupan. Emosi positif dapat berupa rasa bahagia, senang, aman dan tidak ada afek negatif. Sedangkan pandangan eudaimonic menunjukan bahwa untuk mendapatkan level kebahagiaan dan kesejahteraan yang tinggi sesorang harus menunjukan aktualisasi dan potensi dirinya dalam menghadapi tantangan kehidupan (Keyes et al, 2002). Pandangan ini lebih berfokus pada aktivitas-aktivitas seseorang yang mengejar kebahagiaan dan kepuasan untuk diri mereka. Artinya bahwa mereka melakukan berbagai upaya dan cara untuk menggapai hidup yang lebih bermakna bukan dengan cara bersenang-senang namun melakukan hal bermakna. Yang membedakan kedua pandangan ini ialah sifatnya. Pandangan hedonic dapat menciptakan kesejahteraan yang cepat namun dapat bersifat sementara. Sedangkan pandangan eudaimonic dapat menciptakan kesejahteraan yang konsisten dan lebih bertahan lama (Steger et al, 2007). Dalam teori dasar, kesejahteraan dan kebahagiaan yang telah dipaparkan sebelumnya dikenal dengan istilah Well-Being. Istilah ini muncul seiring dengan perkembangan ilmu psikologi positif (Susetyo dkk, 2012).

Huppert, Baylis dan Keverne mendefinisikan well-Being sebagai suatu keadaan positif yang memungkinkan seseorang, kelompok, ataupun suatu negara menjadi sejahtera (dalam Fiona, 2015). Dalam konteks individu, well-being mengacu pada keadaan psikologis, fisik dan sosial yang positif sehingga individu tersebut dapat menjalankan fungsi kehidupannya secara baik dan optimal (Fiona, 2015). Diener dalam tulisannya tentang "New Measures of Well-Being" mengungkapkan bahwa kesejahteraan seseorang dapat dievaluasi dari tiga aspek yaitu afek (perasaan) positif, negatif dan balance 
yang dialami, pemikiran positif dan negatif yang dimiliki, serta kesejahteraan psikologisnya (Diener et al, 2009). Evaluasi afek ini merupakan penilaian individu terhadap suasana hati/ perasaan yang dialami. Tandatanda seseorang dengan afek positif yaitu merasa baik, nyaman, senang, dan puas, sedangkan afek negatif meliputi perasaan buruk, tidak menyenangkan, sedih, takut dan marah (Diener et al, 2009). Seseorang yang memiliki afek positif berkemungkinan untuk dapat memiliki pemikiran positif. Dengan adanya pemikiran positif seseorang akan cenderung menjalani hidup dengan rasa syukur. Selain itu kesejahteraan psikologis juga memiliki peran yang penting dalam kesehatan mental seseorang. Kesejahteraan psikologis tersebut dapat dilihat dari beberapa dimensi yaitu penerimaan diri, hubungan positif, otonom, penguasaan lingkungan, tujuan hidup dan pengembangan pribadi (Ryff, 1995).

Well-being seseorang salah satunya dipengaruhi oleh faktor sosiodemografis seperti usia, jenis kelamin, status sosial ekonomi, budaya (Ryff dan Keyes, 1995), pekerjaan dan status pernikahan (Oktavinur dan Fikri, 2017). Pada penelitian yang dilakukan
Karasawan dkk menunjukkan bahwa usia dapat mempengaruhi well-being (Karawasa et al, 2011). Hasil penelitiannya menunjukkan bahwa pada orang dewasa yang lebih tua memiliki skor yang tinggi dalam hal mengalami pertumbuhan pribadi yang artinya mereka sudah melewati tahaptahap perkembangan hidup dan menyadari tentang potensi-potensi diri yang sudah dilakukan selama itu. Sedangkan pada penelitian Ryff dan Keyes yang berjudul "The Structure of Psychological Well-Being Revisited" menunjukkan bahwa perbedaan usia dapat mempengaruhi aspek-aspek dalam well-being (Ryff dan Keyes, 1995). Dijelaskan bahwa, seiring dengan bertambahnya usia seseorang akan cenderung memiliki kemampuan penguasaan lingkungan dan otonomi dalam dirinya. Penelitiannya juga menunjukkan bahwa jenis kelamin memberikan pengaruh dalam wellbeing yang menunjukkan wanita lebih memiliki skor yang tinggi pada aspek hubungan positif dengan orang lain dibanding dengan laki-laki. Ini menjadi salah satu aspek bahwa wanita dapat membangun well-being mereka dengan menjalin hubungan baik dengan orang disekitar, karena hubungan dan relasi merupakan salah satu komponen dalam 
kesehatan mental seseorang. Sehingga hal ini juga sangat berperan dalam wellbeing. Terkait dengan itu penelitian lain juga menyatakan bahwa perempuan memiliki tingkat well-being yang lebih tinggi dibandingkan dengan laki-laki. Hal ini dapat dilihat dari beberapa aspek yaitu pengalaman spiritual, hubungan positif dengan orang lain dan tujuan hidup (Perez dan Jeannie, 2012 dalam Simarmata, 2015). Faktor demografi lainnya yang juga mempengaruhi well-being seseorang ialah status sosial ekonomi. Dalam penelitian yang dilakukan oleh Wenas, Opod dan Pali menemukan bahwa terdapat hubungan antara kebahagiaan dengan status sosial ekonomi (Wenas dkk, 2015). Seseorang yang menempati kelas sosial tinggi yang memiliki pendidikan, pekerjaan dan penghasilan yang baik akan meningkatkan well-beingnya, terutama dalam aspek penerimaan diri dan aspek tujuan hidup (Ryff, 1995). Sedangkan penilitian yang dilakukan oleh Biswas- Diener dan Diener di Calcutta menemukan bahwa orangorang penghuni daerah kumuh tidak selalu menunjukkan kepuasan hidup yang rendah dibandingkan dengan orang-orang yang lebih kaya dari mereka (dalam Royo dan Velazco,
2006). Hal ini terjadi karena mereka lebih mementingkan hubungan sosial dan kepuasan tersendiri terhadap apa yang mereka miliki. Sama halnya dengan yang dinyatakan Royo dan Velazco bahwa ketika orang-orang yang berstatus sosial ekonomi rendah diperhadapkan dengan pertanyaan tentang kebahagiaan atau kesejahteraan maka mereka akan lebih mengutamakan hal-hal lain yang menjadi sumber kebahagiaan seperti hubungan sosial, dukungan sosial dan hal-hal pribadi lainnya dibandingkan dengan pendidikan, jenis rumah, perawatan dan kesehatan (Royo dan Velazco, 2006).

Pada faktor pekerjaan, Argyle dalam Fikri dan Oktavinur mendefinisikan bahwa umumnya orang yang bekerja akan lebih memiliki kebahagiaan yang tinggi dibandingkan dengan mereka yang tidak bekerja (Oktavinur dan Fikri, 2017). Salah satu hal yang mengakibatkan mereka yang tidak bekerja (pengangguran) tidak bahagia disebabkan karena afek positif dalam dirinya berkurang. Hal lain pada faktor pernikahan menurut Eddington dkk menunjukan bahwa pernikahan memiliki hubungan dengan kebahagiaan. Menurutnya bahwa mereka yang menikah akan lebih 
bahagia dibandingkan dengan mereka yang tidak menikah ataupun bercerai (dalam Oktavinur dan Fikri, 2017). Di Indonesia, survei terbaru tentang tingkat kebahagiaan dilakukan oleh Badan Pusat Statistik (BPS) ialah pada tahun 2014. Hasil survei yang dirilis BPS menunjukkan hasil bahwa terdapat 3 provinsi yang memiliki indeks kebahagiaan tertinggi antara lain Riau dengan indeks 72,42; Maluku dengan indeks 72,12 dan Kalimantan Timur dengan indeks 71,45 (Media Online; Kabar24bisnis.com, 2015). Survei kebahagiaan ini menggunakan pendekatan kepuasan hidup yang disusun dalam 10 aspek kehidupan yaitu kesehatan, pendidikan, pekerjaan, pendapatan rumah tangga, keharmonisan keluarga, ketersediaan waktu luang, hubungan sosial, kondisi rumah/ aset, keadaan lingkungan dan kondisi keamanan. Jika ditilik secara teoritis, kepuasan hidup adalah bagian dari evaluasi subjective well-being (SWB), sehingga dapat dikatakan bahwa, survey yang dilakukan oleh BPS belum mencakup keseluruhan aspek dalam well-being.

Menarik untuk diteliti, meskipun menempati urutan kedua dengan tingginya tingkat kebahagiaan, pada kenyataannya Maluku menduduki urutan keempat dalam masalah kemiskinan di Indonesia (Media online; Tribun-Maluku.com, 2015). Hal ini memperkuat dukungan terhadap pernyataan pada paragraf sebelumnya bahwa survey BPS menggunakan evaluasi SWB dan tidak menghubungkannya dengan aspek sosiodemografi (Media online; TribunMaluku.com, 2015).

Provinsi Maluku terbagi atas 9 kabupaten dan 2 kota, salah satunya Kota Ambon. Kota Ambon merupakan Ibukota Provinsi yang memiliki tingkat kepadatan penduduk tertinggi di Maluku (Profil Kesehatan Maluku, 2014). Jumlah penduduk Kota Ambon tahun 2015 dalam indikator kesejahteraan rakyat Kota Ambon adalah sebanyak 411.617 jiwa dengan komposisi laki-laki sebanyak 205.684 jiwa dan perempuan sebanyak 205.933 jiwa (Indikator Kesejahteraan Rakyat Kota Ambon, 2015).

Ditinjau dari profil demografi, tingkat pendidikan masyarakat kota Ambon bervariasi dari yang tidak bersekolah hingga lulusan S3. Demikian halnya dengan jenis pekerjaan yang bervariasi mulai dari tidak bekerja, bersekolah, PNS, Ibu Rumah Tangga, pegawai swasta, wirausaha dan lain-lain. Sementara 
untuk status status perkawinan, sebesar 45,93\% penduduk belum kawin, kawin $47,59 \%$, cerai hidup $1,55 \%$ dan cerai mati sebanyak 4,93\%. Pada komposisi usia, penduduk Kota Ambon tahun 2015 didominasi oleh struktur usia produktif (usia 15-64 tahun) yaitu sebanyak 285.136 jiwa, diikuti oleh usia muda (0-14 tahun) sebanyak 111.359 jiwa dan usia lanjut (65 tahun ke atas) sebanyak 15.122 jiwa (Indikator Kesejahteraan Rakyat Kota Ambon, 2015).

Tujuan dari penelitian ini ialah untuk mengidentidikasi dan mendeskripsikan profil sosiodemografi (usia, jenis kelamin, latar belakang pendidikan, jenis pekerjaan, pendapatan per bulan, dan status perkawinan), tingkat well-being yang diukur dari 3 aspek yaitu afek positif dan negatif, pemikiran positif atau negatif dan kesejahteraan psikologis, serta adakah hubungan antara sosiodemografi dengan tingkat wellbeing pada masyarakat Kota Ambon, Maluku.

\section{Hasil Penelitian}

1. Deskripsi Profil

\section{Sosiodemografi Responden}

Profil sosiodemografi didata dengan tujuan untuk melihat latarbelakang masing-masing responden. Profil sosiodemografi meliputi sub variabel usia, jenis kelamin, pendidikan, pekerjaan, pendapatan perbulan dan status perkawinan. Pada penelitian ini dipaparkan dalam tabel 1.1. 
Tabel 1.1 Profil sosiodemografi responden

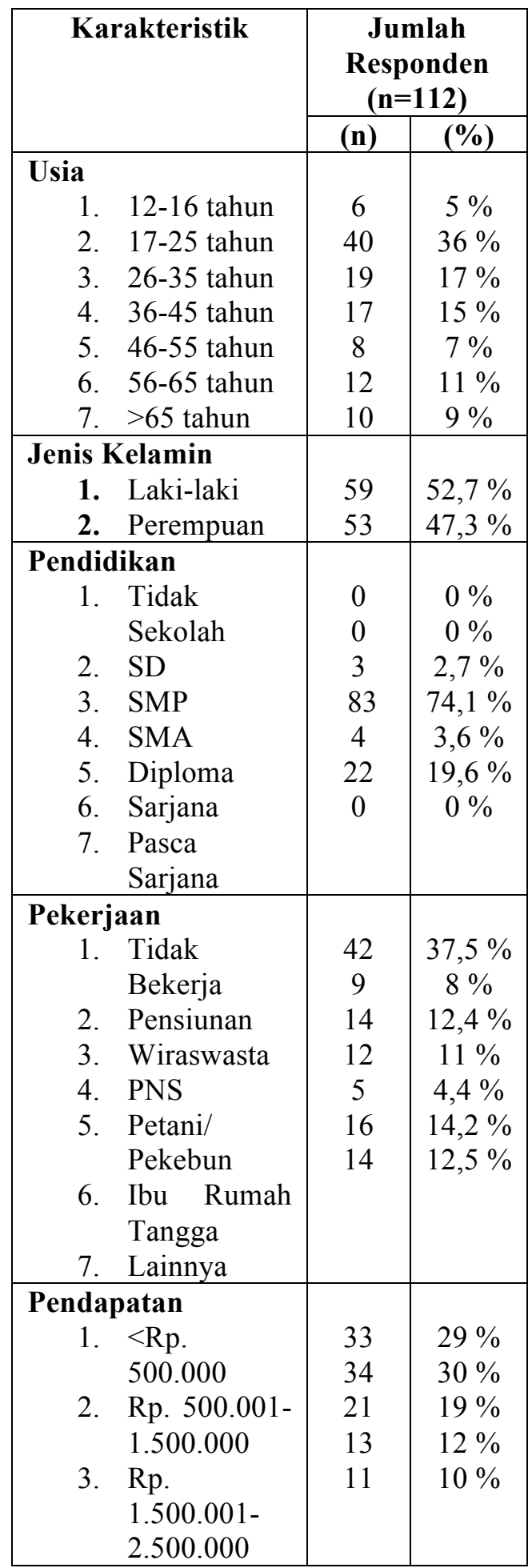

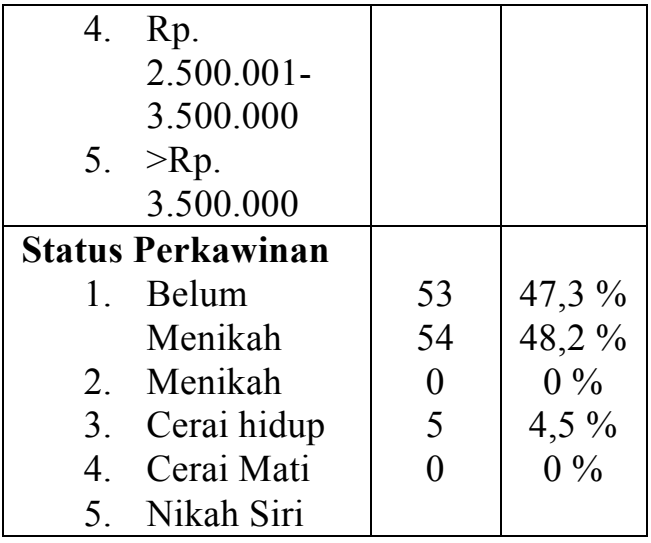

Tabel di atas menunjukkan bahwa responden yang berusia 17-25 tahun yaitu sebanyak 40 responden, usia 26-35 tahun sebanyak 19 responden, usia 36-45 tahun sebanyak 17 responden, usia 56-65 tahun sebanyak 12 responden, $>65$ tahun sebanyak 10 responden, usia 46-55 tahun sebanyak 8 responden dan yang paling sedikit pada usia 12-16 yaitu sebanyak 6 responden. Responden berjenis kelamin laki-laki sebanyak 59 responden dan perempuan sebanyak 53 responden. Karakteristik pendidikan responden paling banyak yaitu pada responden dengan latar belakang pendidikan SMA sebanyak 83 responden $(74,1 \%)$, diikuti oleh sarjana sebanyak 22 , diploma sebanyak 4 dan SMP sebanyak 3 responden. Responden yang tidak bekerja sebanyak 42 responden, pensiunan 9 responden, wiraswasta 14 responden, PNS 12 responden, petani/ pekebun 5 responden, ibu rumah tangga 
16 responden dan lainnya sebanyak 14 responden. Responden yang berpendapatan sebesar $<$ Rp. 500.000 sebanyak 33 responden,. Rp. 500.0011.500.000 sebanyak 34 responden, 21 responden berpendapat Rp. 1.500.0012.500.000, 13 responden berpendapat 2.500.001- 3.500.000 dan responden yang berpendapatan sebesar >Rp. 3.500.001 sebanyak 11 responden. Status perkawinan responden yang belum menikah dan menikah hanya berbeda 1 angka yaitu belum menikah sebanyak 53 responden dan yang menikah sebanyak
2.1. Scale of Positive and Negative Experince (SPANE)

Skala ini merupakan skala yang dipakai untuk mengukur afek positif dan negatif seseorang yang dirasakan selama 4 minggu terakhir mereka. Dalam skala ini digunakan 5 kategori untuk menginterpretasi tingkatannya. Setelah peneliti mengambil data dan melakukan tabulasi serta analisa data maka hasil dapat dilihat pada tabel berikut ini:

Tabel 2.1.1 Scale of Positive and

\begin{tabular}{|c|c|c|c|}
\hline $\begin{array}{l}54 \text { responden } \\
\text { serta pada }\end{array}$ & $\begin{array}{c}\text { Skala } \\
\text { (SPANE) }\end{array}$ & Jum & $\begin{array}{l}\text { Responden } \\
1=112)\end{array}$ \\
\hline & & $(\mathrm{n})$ & $(\%)$ \\
\hline onden & 1. Selalu mengalami perasaan positif & 4 & $3,6 \%$ \\
\hline cerai & 2. Sering mengalami perasaan positif & 52 & $46,4 \%$ \\
\hline terdapat & $\begin{array}{l}\text { 3. Kadang-kadang mengalami perasaan positif } \\
\text { 4. Jarang mengalami perasaan positif }\end{array}$ & 50 & $45 \%$ \\
\hline sebanyak & 5. Tidak pernah mengalami perasaan positif & 6 & $5 \%$ \\
\hline & & 0 & $0 \%$ \\
\hline
\end{tabular}

\section{Well-Being}

Well-being adalah suatu konsep umum yang dalam pengukurannya melibatkan banyak aspek seperti pengalaman perasaan/emosi, pemikiran positif/negatif dan kesejahteraan psokologis.
Berdasarkan tabel 2.1.1 maka dapat diketahui pada SPANE responden yang selalu mengalami afek positif terdapat sebanyak 4 responden $(3,6 \%)$, sering mengalami afek positif 52 responden (46,4\%), kadangkadang mengalami afek positif 
sebanyak 50 responden (45\%), jarang mengalami afek positif sebanyak 6 responden $(5 \%)$ dan tidak ada dari responden yang tidak pernah mengalami afek positif.

2.2. Positive Thinking Scale (PTS) Positive Thinking Scale merupakan skala yang digunakan untuk mengukur pemikiran positif dan negatif seseorang. Dari hasil tabulasi yang sudah dilakukan maka untuk melihat tingkat pemikiran positif dan negatif responden maka disajikan chart di bawah ini.

Chart 2.2.1 Positive Thinking Scale (PTS)

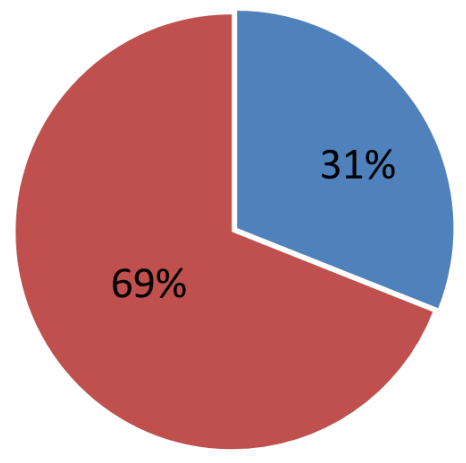

Pada PTS, responden yang berpikir paling positif menduduki urutan pertama yaitu sebanyak 77 responden atau $69 \%$ dan 35 responden atau $31 \%$ yang memiliki cara berpikir paling negatif.

2.3. Scale of Psychological Well-Being (PWB).

Skala ini merupakan skala yang digunakan untuk mengukur kesejahteraan psikologis seseorang. Dalam skala ini digunakan 5 kategori yaitu sangat tinggi, tinggi, sedang, rendah dan sangat rendah. Hasil tabulasi yang sudah dilakukan dapat dilihat pada tabel di bawah ini.

$$
\begin{aligned}
& \text { Berpikir } \\
& \text { paling negatif } \\
& \text { Berpikir } \\
& \text { paling positif }
\end{aligned}
$$


pendidikan, pekerjaan, pendapatan dan status perkawianan.

3.1.Scale of Positive and Negative

\begin{tabular}{|l|lr|l|}
\hline Variabel & $\begin{array}{l}\text { Pengujian Analisis Korelasi } \\
\text { Pearson Product moment) }\end{array}$ & $\begin{array}{l}\text { Interpretasi } \\
(\mathrm{a}=0,05)\end{array}$ \\
\hline SPANE dan Usia & $\mathrm{r}=0,096$ & $\mathrm{p}$-value $=0,314$ & Tidak signifikan \\
SPANE dan Jenis Kelamin & $\mathrm{r}=0,042$ & $\mathrm{p}$-value $=0,657$ & Tidak signifikan \\
SPANE dan Pendidikan & $\mathrm{r}=-0,038$ & $\mathrm{p}$-value $=0,691$ & Tidak signifikan \\
SPANE dan Pekerjaan & $\mathrm{r}=0,072$ & $\mathrm{p}$-value $=0,449$ & Tidak signifikan \\
SPANE dan Pendapatan & $\mathrm{r}=-0,078$ & $\mathrm{p}$-value $=0,415$ & Tidak signifikan \\
SPANE dan Status Perkawinan & $\mathrm{r}=0,005$ & $\mathrm{p}$-value $=0,957$ & Tidak signifikan \\
\hline
\end{tabular}

Tabel 2.3.1 Scale of Psychological

Well-Being (PWB)

sosiodemografi

Pada tabel dibawah ini,

\begin{tabular}{|c|c|c|}
\hline \multirow[t]{2}{*}{$\begin{array}{c}\text { Skala } \\
\text { (PWB) }\end{array}$} & \multicolumn{2}{|c|}{$\begin{array}{l}\text { Jumlah Responden } \\
(\mathrm{n}=112)\end{array}$} \\
\hline & (n) & $(\%)$ \\
\hline 1. Memiliki kesejateraan psikologi yang sangat tinggi & 11 & $10 \%$ \\
\hline 2. Memiliki kesejateraan psikologi yang tinggi & 74 & $66 \%$ \\
\hline 3. Memiliki kesejateraan psikologi yang sedang & 25 & $22 \%$ \\
\hline 4. Memiliki kesejateraan psikologi yang rendah & 2 & $2 \%$ \\
\hline 5. Memiliki kesejateraan psikologi yang sangat rendah & 0 & $0 \%$ \\
\hline
\end{tabular}

Dalam perhitungan skala didipaparkan hasil uji statistik

PWB mendapatkan bahwa

responden paling banyak memiliki

kesejahteraan psikologis yang

tinggi yaitu sebanyak 74 responden

atau $66 \%$.

\section{Well-being dan Sosiodemografi}

terkait hubungan antara well-

being: afek positif dan negatif

terhadap sosiodemografi.

Tabel 3.1 Hasil uji korelasi

SPANE dan Sosiodemografi

Inti dari penelitian ini adalah untuk mencari tahu hubungan antara wellbeing: Scale of Positive and Negative Experince (SPANE), Positive Thinking Scale (PTS) dan Scale of Psychological Well-Being (PWB) dengan profil sosiodemografi: usia, jenis kelamin,

Tabel di atas menjelaskan bahwa tidak terdapat hubungan yang signifikan antara wellbeing; afek positif atau negatif dengan faktor sosiodemografi. Hal ini ditunjukkan pada nilai signifikan yang lebih besar daripada $p$-value. 


\begin{tabular}{|l|ll|l|}
\hline Variabel & $\begin{array}{l}\text { Pengujian } \\
\text { (Analisis Korelasi Pearson Product } \\
\text { Moment })\end{array}$ & $\begin{array}{l}\text { Interpretasi } \\
(\mathrm{a}=0,05)\end{array}$ \\
\hline PWB dan Usia & $\mathrm{r}=0,273$ & $\mathrm{p}$-value $=0,004$ & Signifikan \\
PWB dan Jenis Kelamin & $\mathrm{r}=0,103$ & $\mathrm{p}$-value $=0,281$ & Tidak signifikan \\
PWB dan Pendidikan & $\mathrm{r}=-0,111$ & $\mathrm{p}$-value $=0,245$ & Tidak signifikan \\
PWB dan Pekerjaan & $\mathrm{r}=0,227$ & $\mathrm{p}$-value $=0,016$ & Signifikan \\
PWB dan Pendapatan & $\mathrm{r}=-0,041$ & $\mathrm{p}$-value $=0,670$ & Tidak signifikan \\
PWB dan Status Perkawinan & $\mathrm{r}=0,164$ & $\mathrm{p}$-value $=0,084$ & Tidak signifikan \\
\hline
\end{tabular}

3.2. Positive Thinking Scale (PTS) 3.3. Scale of Psychological Well-Being

Uji statistik korelasi antara

pemikiran positif dan negatif

terhadap faktor sosiodemografi

ditampilkan dalam tabel 3.2

Tabel 3.2 Hasil uji korelasi PTS

dan Sosiodemografi
(PWB) dan sosiodemografi

Tabel 3.3. dibawah ini menampilkan hasil dan interpretasi data uji korelasi antara tingkat kesejahteraan psikologis dengan profil sosiodemografi.

Tabel 3.3 Hasil uji korelasi PWB

\begin{tabular}{|l|ll|l|}
\hline Variabel & \multicolumn{2}{|l|}{$\begin{array}{l}\text { Pengujian } \\
\text { (Analisis Korelasi Pearson Product } \\
\text { moment) }\end{array}$} & $\begin{array}{l}\text { Interpretasi } \\
(\mathrm{a}=0,05)\end{array}$ \\
\hline PTS dan Usia & $\mathrm{r}=-0,013$ & $\mathrm{p}$-value $=0,893$ & Tidak signifikan \\
PTS dan Jenis Kelamin & $\mathrm{r}=-0,055$ & p-value $=0,561$ & Tidak signifikan \\
PTS dan Pendidikan & $\mathrm{r}=0,001$ & p-value $=0,988$ & Tidak signifikan \\
PTS dan Pekerjaan & $\mathrm{r}=-0,211$ & p-value $=0,025$ & Signifikan \\
PTS dan Pendapatan & $\mathrm{r}=0,040$ & p-value $=0,673$ & Tidak signifikan \\
PTS dan Status Perkawinan & $\mathrm{r}=0,015$ & p-value $=0,873$ & Tidak signifikan \\
\hline
\end{tabular}

Tabel 3.2 menampilkan

hasil bahwa tidak terdapat

hubungan yang signifikan antara

well-being; pemikiran positif dan

negatif dengan 5 variabel

sosiodemografi yaitu uisa, jenis

kelamin, pendidikan, pendapatan

dan status perkawinan

dikarenakan $p$-value lebih besar

dari taraf signifikansi. dan Sosiodemografi

Dari tabel di atas, menunjukkan bahwa ada 2 dari 6 faktor sosiodemografi yang memiliki hubungan signifikan dengan pemikiran positif dan negatif, yaitu usia dan pekerjaan. Ini dapat dilihat pada $p$-value yang lebih kecil angkanya dari taraf signifikansi penelitian ini.

\section{Pembahasan}




\section{Profil Sosiodemografi Responden}

Penelitian ini menunjukkan bahwa sebagian besar responden ada dalam kategori usia produktif. Hal ini didukung oleh data yang ditemukan dalam Rencana Kerja Pembangunan Daerah Kota Ambon tahun 2016 bahwa masyarakat kota Ambon didominasi oleh usia produktif sebanyak 68,46\% (Peraturan Walikota Ambon Nomor 19, 2015).

Sebanyak 40 responden ada pada rentang usia 17-25 tahun dapat dijadikan kemungkinan alasan mengapa pada tingkat pendidikan responden didominasi oleh mereka yang latar belakang pendidikannya ialah SMA yaitu sebanyak 83 responden $(74,1 \%)$. Hal ini jugalah yang kemudian turut mempengaruhi jumlah responden yang tidak bekerja menduduki posisi terbanyak yaitu sebesar 37,5\%. Tidak hanya itu, masuknya kategori pendapatan pada level rendah (Rp. 500.001- Rp. 1.500.000) dan sangat rendah $(<$ Rp. 500.000) pun mendukung hasil sub variabel sosiodemografi yang telah disebutkan di atas.

\section{Tingkat Well-being}

Tingkat well-being responden diukur dari 3 hal yaitu afek positif dan negatif, pemikiran positif dan negatifnya, serta tingkat kesejahteraan psikologis. Penelitian ini memberikan hasil bahwa rata-rata responden sering mengalami perasaan positif. Hal ini dimungkinkan karena responden dalam penelitian ini banyak yang ada dalam kategori usia produktif dan sebagian masih ada di bangku pendidikan maka tidak menutup kemungkinan mereka sering menghabiskan waktu mereka dengan melakukan kegiatan-kegiatan positif bersama orang-orang disekitar. Hal ini sejalan dengan penelitian yang dilakukan oleh Elfida dkk bahwa hubungan sosial adalah faktor yang sangat dominan dalam memunculkan kebahagiaan serta pihak yang mendukung dirasakannya kebahagiaan adalah keluarga dan teman (Efilda dkk, 2014). Sama halnya dengan penelitian Yulianti dan Harmaini menemukan bahwa peristiwa yang membuat seorang remaja bahagia adalah peristiwa yang melibatkan suatu relasi (58,0\%). Relasi yang dimaksud adalah relasi dengan orang tua, keluarga dan teman (Yulianti dan Harmaini, 2014). 
Pada pengukuran pemikiran positif (PTS) sebagian besar responden ada dalam kategori memiliki cara berpikir paling positif. Responden mungkin memiliki pemikiran positif kerena dipengaruhi oleh pengalaman dan perasaan mereka sehari-hari yang baik. Responden dalam penelitian ini adalah masyarakat yang hidup di lingkungan yang memiliki relasi yang baik. Setiap minggunya masyarakat selalu terlibat dalam kegiatan ibadah baik di tempat ibadah (gereja) ataupun kunjungan persekutuan tiap rumah. Hal positif ini dapat membuat masyarakat untuk selalu bersyukur atas hidupnya dan dengan begitu dapat meningkatkan pemikiran positif mereka. Hal ini juga yang memberikan pengaruh dalam kesejahteraan psikologis masyarakat yang ditemukan dalam hasil penelitian bahwa sebagian responden memiliki kesejahteraan psikologis yang tinggi. Seperti penelitian yang dilakukan oleh Amawidyati dan Utami yang mendapatkan hasil bahwa ada hubungan antara religiutas seseorang dengan kesejahteraan psikologis (Amawidyati dan Utami, 2007). Dalam penelitiannya masyarakat yang ada dalam beban psikologis yang berat dapat bertahan ditengah keadaannya karena memiliki kepercayaan yang kuat terhadap agamanya. Begitupun rasa syukur akan membangkitkan kembali kesejahteraan psikologis seseorang. Mengingat bahwa dalam penelitian ini banyak responden memiliki kesejahteraan psikologis yang tinggi yaitu sebanyak sebesar $66 \%$. Hal inilah yang mungkin memberikan pengaruh dalam kesejahteraan psikologis mereka.

\section{Hubungan Well-being dengan Sosiodemografi}

Penelitian ini bertujuan untuk mengetahui hubungan antara well-being; perasaan positif atau negatif (SPANE), berpikir positif dan negatif (PTS) serta kesejateraan psikologis (PWB) dengan faktor sosiodemografi; usia, jenis kelamin, pendidikan, pekerjaan, pendapatan dan status perkawinan.

Hasil penelitian ini ditemukan bahwa tidak terdapat hubungan yang signifikan antara well-being; perasaan positif atau negatif (SPANE) dengan faktor sosiodemografi. Penelitian ini tidak sejalan dengan penelitian yang dilakukan oleh Simarmata. Dalam penelitiannya yang melibatkan salah satu 
faktor sosiodemografi (pekerjaan) menemukan bahwa kepuasan kerja memiliki hubungan yang erat dengan well-being (Simarmata, 2015). Hal ini dapat disebabkan karena pekerjaan merupakan bagian yang penting dalam kehidupan seseorang. Artinya seseorang bekerja karena untuk memenuhi kebutuhan mereka yang tentunya akan meningkatkan well-being mereka. Dalam penelitianya bila seorang karyawan puas dengan pekerjaannya maka akan meningkatkan well-being-nya.

Sedangkan pada penelitian ini menunjukkan bahwa tidak terdapat hubungan. Ini memberikan arti bahwa pada dasarnya setiap orang memiliki tujuan hidup untuk meraih kebahagiaan baik mereka yang berusia produktif, lansia, bekerja, tidak bekerja, masih sekolah, menikah, belum menikah dan lain sebagainya. Ini menunjukkan bahwa kebahagiaan tidak selalu didasarkan pada status sosiodemografi. Seperti yang dikemukakan oleh Diponegoro dan Mulyono bahwa kebahagiaan merupakan sesuatu yang ingin dicapai setiap orang baik yang kaya, miskin, pejabat maupun buruh (Diponegoro dan Mulyono, 2015). Dikatakan pula bahwa permasalahan yang dialami setiap orang tidak akan membatasi mereka untuk berhenti mengejar dan mencari kebahagiaan. Dilihat pada keterlibatan banyak orang dalam rentang usia 17-25 tahun pada penelitian ini, dapat mengindikasikan bahwa sebagian responden masih dalam masa pendidikan/sekolah atau bahkan belum memiliki pekerjaan dengan status tidak bekerja. Namun mereka akan berusaha mencari hal yang membuat mereka memiliki afek positif. Pada rentang usia ini juga, mereka sedang dalam masa pencarian jati diri dimana mereka akan lebih banyak mencari kesenangan bersama teman-teman sebaya (Boero, 2006).

Pun selanjutnya, tidak terdapat hubungan yang signifikan antara wellbeing; pemikiran positif dan negatif (PTS) dengan 5 faktor sosiodemografi terkecuali pada faktor pekerjaan. Dalam penelitian yang dilakukan oleh Wenas dkk tahun 2015 menemukan bahwa kebahagiaan memiliki hubungan dengan status sosial ekonomi namun dengan tingkat hubungan yang rendah yang berarti bahwa kebahagiaan tidak selamanya ditentukan oleh status sosial ekonomi yang salah satunya adalah 
pendapatan (Wenas dkk, 2015). Menurutnya kebahagiaan dapat terwujud bila adanya rasa aman, nyaman, saling mencintai dan menghargai walaupun seseorang dalam kondisi status ekonomi yang rendah (Wenas dkk, 2015). Hal tersebut memberikan arti bahwa kebahagiaan bisa didapat salah satunya dengan berpikir positif. Pendapatan hanya faktor pendukung yang bisa terus diusakan dengan berpikir positif.

Begitupun pada responden dalam penelitian ini. Faktor yang mungkin dapat membuat mereka memiliki pemikiran positif yaitu dengan adanya dukungan keluarga, relasi yang baik dengan orang disekitar, lingkungan, religiutas dan lainnya. Diketahui bahwa masyarakat di Ambon masih sangat memegang nilai budaya yang salah satunya adalah "Pela Gandong". Pela gandong merupakan istilah yang menjelaskan tentang hubungan persaudaraan di tengah perbedaan masyarakat Ambon. Dengan ini maka hubungan antar masyarakat akan dijaga nilai kekeluargaannya dan itu dapat dirasakan oleh siapa saja baik mereka yang muda, tua, status sosial ekonomi yang rendah atau tinggi, menikah, belum menikah dan lain sebagainya. Hal ini menggambarkan suatu keharmonisan antar sesama, karena jika ada yang susah maka masyarakat akan saling tolong menolong. Relasi yang baik inilah yang dapat memberikan pemikiran yang positif dalam diri mereka. Namun disisi lain pada faktor pekerjaan yang memiliki hubungan signifikan dengan pemikiran positif dan negatif menunjukkan bahwa pekerjaan juga dapat memberikan pengaruh terhadap seseorang dalam menilai sesuatu. Pemikiran yang positif akan ada ketika seseorang memiliki pekerjaan (kecuali yang masih sekolah) yang membuatnya merasa nyaman, senang dan sesuai bidangnya.

Sedangkan pada pengukuran well-being: kesejahteraan psikologis, terdapat hubungan yang signifikan dengan faktor usia dan pekerjaan. Hasil ini hampir serupa dengan penelitian Rahayu yang menemukan bahwa usia dan kebahagiaan memiliki hubungan yang membentuk seperti huruf $U$ (Rahayu, 2016). Dijelaskan bahwa semakin tinggi usia seseorang maka semakin rendah kebahagiaan namun pada titik tertentu semakin bertambahnya usia seseorang akan lebih bahagia. Ia 
mencontohkan bahwa hal-hal yang membuat terjadi perubahan psikologis dalam kehidupan seorang yang sudah lanjut usia seperti perasaan tersisih, tidak dibutuhkan lagi, tidak menerima kematian pasangan, penyakit dan lainnya (Rahayu, 2016). Namun disisi lain dengan adanya peningkatan usia maka seseorang juga akan memiliki kemampuan untuk beradaptasi dan mengolah perasaannya. Lain halnya dengan pekerjaan, tekanan psikologis yang besar akan dirasakan oleh mereka yang tidak memiliki pekerjaan (kecuali mereka yang sedang bersekolah). Stigma tentang ketidakmampuan dan tidak berkualitasnya seseorang kadang masih disematkan kepada mereka yang belum beruntung dengan pekerjaan mereka.

\section{Kesimpulan}

Dari penelitian ini dapat disimpulkan bahwa responden yang paling banyak adalah responden pada usia produktif 17-25 tahun (36\%), berjenis kelamin laki-laki (52,7\%), pendidikan SMA (74,1\%), tidak bekerja (37,5\%), berpendapatan Rp. 500.001$1.500 .000(30 \%)$ dan status pernikahan menikah $(48,2 \%)$.
Tingkat well-being yang ditemukan paling tertinggi dalam setiap skala yaitu SPANE: sering mengalami perasaan positif $(46,4 \%)$, PTS: berpikir paling positif (69\%) dan PWB: kesejahteraan psikologis yang tinggi (66\%). Hal ini disebabkan karena masyarakat memiliki relasi yang baik antar sesama.

Pada variabel sosiodemografi hanya ada 2 subvariabel yaitu usia dan pekerjaan yang memiliki hubungan dengan kesejahteraan psikologis, sedangkan pada variabel afek positif dan negatif serta pemikiran positif dan negatif tidak memiliki hubungan yang signifikan dengan variabel sosiodemografi kecuali pekerjaan dengan pemikiran positif dan negatif. Hal ini menunjukkan bahwa kesejahteraan seseorang tidak selalu berhubungan dengan faktor sosiodemografi seperti usia, jenis kelamin, pendidikan, pekerjaan, pendapatan dan status perkawinan. Ada faktor lain yang bisa membuat seseorang menjadi bahagia dan sejahtera seperti relasi yang baik dengan Tuhan dan sesama. 


\section{Saran}

Faktor-faktor lain seperti budaya, lingkungan, relasi mungkin dapat memiliki hubungan dengan well-being yang dalam penelitian ini tidak diujikan sehingga ini menjadi keterbatasan dalam penelitian ini.

\section{Daftar Pustaka}

Amawidyati S A G, Utami M S. (2007). Religiutas dan psychological well-being pada korban gempa. Jurnal Psikologi, 2 (34), 164-176

Ariyanti, D S. (2015, February 05). Penduduk di 3 provinsi ini paling bahagia se- Indonesia. Media Online; Kabar24bisnis.com, 05 februari, 2015. Retrieved from http://kabar24.bisnis.com/read/2015020 5/15/399268/penduduk-di-3-provinsiini-paling-bahagia-se-indonesia

Boere, C. G. (2006) Personality theories Erik Erikson 1902-1994. Psycholgy Departement Shippensburg University, $1-17$

Djabumir, N. (2016). Hubungan antara family functioning dan psychological wellbeing pada emerging adulthood. Jurnal Ilmiah Mahasiswa Universitas Surabaya. 5(1), 1-16

Diener Ed, Wirtz D, Diener R B, Tov W, Prieto C K, Choi DW, Oishi S. (2009). New measures of well-being. In: Diener E. (eds) Assesing Well-Being. Social
Indicators Research Series 39, 247-266. doi: 10.1007/978-90-481-2354-4_12.

Diponegoro A M, Mulyono. (2015). Faktor-faktor psikologis yang mempengaruhi kebahagiaan pada lanjut usia suku Jawa di Klaten. Psikopedagogia, 4 (1), 13-19

Efilda D, Lestari Y I, Diamera A, Angraeni R, Islami S. (2014). Hubungan baik dengan orang yang signifikan dan kontribusinya terhadap kebahagiaan remaja Indonesia. Jurnal Psikologi, 10 (2), 66-73

Fiona. (2015). Wellbeing concepts and challenges. Discussion paper; Sustainable development research Network.

Indikator kesejahteraan rakyat Kota Ambon 2015: Badan pusat statistik Kota Ambon. Retrieved from https://ambonkota.bps.go.id/

Keyes, C L M., Ryff, C D., and Shmotkin, D. (2002). Optimizing wellbeing : The empirical encounter of two traditions. Journal of Personality and Social Psychology, 82 (6), 959-97

Karasawa, Churchan K B, Markus H R, Kitayama S S, Dienberg L G, Radler B T, Ryff, C. D. (2011). Cultural perspectives on aging and well-being: A comparison of Japan and the U.S. Int J Aging Hum Dev, 73 (1): 73-98. doi: 10.2190/AG.73.1.d

Oktavinur S S, Fikri H T. (2017). Kebahagiaan pada istri yang menjalani 
pernikahan jarak jauh. Jurnal PSYCHE 165 fakultas psikologi, 10(1), 19-28

Profil Kesehatan Maluku. (2014). Dinas Kesehatan Provinsi Maluku.

Peraturan Walikota Ambon Nomor 19 tahun 2015: Rencana kerja pembangunan daerah (RKPD) Kota Ambon Tahun 2016

Ryff, C. D. (1995) Psychological wellbeing in adult life. Cambridge University Press, 4(4), 99-104

Ryff, C. D, Keyes, C. L. M. (1995). The structure of psychological well-being revisited. Journal of Personality and Social Psychology, 69(4), 719-727

Royo, M. G \& Velazco, J. (2006). Exploring the relationship between happiness, objective and subjective wellbeing: Evidence From Rural Thailand. WeD Working Paper 16

Rahayu T P. (2016). Determinan kebahagiaan di Indonesia. Jurnal Ekonomi dan Bisnis, 19(1), 149-170

Redaksi. Indeks kebahagiaan diperoleh secara subjektif. (2015). Media Online; Tribun-Maluku.com, 03 Maret 2015. Retrieved from http://www.tribunmaluku.com/2015/03/indekskebahagiaan-diperoleh-secara.html

Steger, M F., Kashdan, T. Oishi, S. (2008). Being good by doing good: daily eudaimonic activity and well-being. Journal of Research in Personality, 42(1), 22-42
Susetyo Y F, Faturochman, Kumara A, Saptandari E W, Istiqomah $\mathrm{N} A$, Kisriyanti A, Helmi A F, Pertiwi Y G, et al. (2012). Psikologi untuk kesejahteraan masyarakat. Yogyakarta: Pustaka Pelajar.

Simarmata N. (2015). Pengaruh kepuasan kerja terhadap well-being karyawan in Pt. Intan havea industry, Medan. 2015. Jurnal Psikologi Universitas HKBP Nommensen, 1(1), ISSN : 2460-7835

Wenas G E, Opod H, Pali C. (2015). Hubungan kebahagiaan dan status sosial ekonomi keluarga di keluraham artembaga II Kota Bitung. Jurnal eBiomedik (eBm), 3(1), 532-538

Yulianti A, Harmaini. (2014). Peristiwaperitiwa yang membuat bahagia. Jurnal Ilmiah Psikologi, 2 (1), 109-119 